\title{
Pengaruh Kualitas Sistem, Kualitas Informasi Akuntansi, Kepuasan Pengguna dan Good Corporate Governance terhadap Kinerja Karyawan (Studi Kasus: PT BPD Bali Cabang Singaraja)
}

\author{
Putu Sri Arumiasih" ${ }^{*}$, Putu Eka Dianita Marvilianti Dewi ${ }^{2}$ iD \\ ${ }^{123}$ Jurusan Ekonomi Dan Akuntansi, Universitas Pendidikan Ganesha, Singaraja, Indonesia \\ *putu.sriarumiasih18@gmail.com.com ${ }^{1 *}$
}

\begin{abstract}
Abstrak
Penelitian ini bertujuan untuk memperoleh bukti empiris pengaruh kualitas sistem, kualitas informasi akuntansi, kepuasan pengguna dan Good Corporate Governance terhadap kinerja karyawan. Penelitian ini merupakan penelitian kausal dengan pendekatan kuantitatif. Populasi dalam penelitian ini adalah seluruh karyawan PT BPD Bali Cabang Singaraja sebanyak 101 orang. Metode pengumpulan data menggunakan metode survei dengan instrument penelitian menggunakan kuesioner. Teknik analisis data menggunakan analisis regresi linear berganda dengan bantuan program SPSS versi 21.00. Hasil penelitian ini menunjukkan bahwa kualitas sistem, kualitas informasi akuntansi, kepuasan pengguna dan Good Corporate Governance berpengaruh positif dan signifikan terhadap kinerja karyawan yang artinya bahwa apabila kualitas sistem, kualitas informasi akuntansi, kepuasan pengguna dan Good Corporate Governance ditingkatkan maka akan berdampak pada peningkatan kinerja karyawan.

Kata Kunci: Kualitas Sistem, Kualitas Informasi Akuntansi, Kepuasan Pengguna, Good Corporate Governance dan Kinerja

\section{Abstract}

This study aimed at obtaining the empirical evidence on the influence of the use of quality of the system, the quality of accounting information, user satisfaction and Good Corporate Governance on company performance. This research is a causal research with a quantitative approach. The population in this study were 101 employees of PT BPD Bali Singaraja Branch. Methods of data collection using survey methods with research instruments using questionnaires. The data analysis technique uses multiple linear regression analysis with the help of the SPSS version 21.00 program. The results of this study indicated that system quality, accounting information quality, user satisfaction and good corporate governance have a positive and significant effect on employee performance, which means that if the quality of the system, the quality of accounting information, user satisfaction and Good Corporate Governance is increased, it will have an impact on improving employee performance.
\end{abstract}

Keywords: System Quality, Quality Of Accounting Information, User Satisfaction, Good Corporate Governance And Performance

\section{Pendahuluan}

Saat ini teknologi berkembang sangat cepat. Hal ini diikuti oleh perkembangan teknologi yang berbasis sistem informasi, oleh sebab itu setiap organisasi sekarang menganggap bahwa sistem informasi sangat penting bagi kelangsungan hidup perusahaan. Sistem informasi (SI) adalah sebuah rangkaiaan prosedur formal dimana data dikumpulkan, diproses menjadi informasi, dan didistribusikan kepada para pemakai (Hall, 2007). Perkembangan SI sangat berkaitan erat dengan akuntansi yang berguna untuk operasional

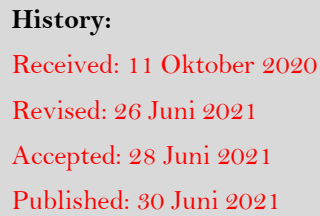

Publisher: Undiksha Press

Licensed: This work is licensed under

a Creative Commons Attribution 3.0 License 
setiap organisasi. Seiring dengan kemajuan dalam bidang teknologi komputer dan informasi dewasa ini, sistem informasi akuntansi telah berkembang menjadi sistem informasi berbasis komputer. Sistem informasi akuntansi yang terkomputerisasi memungkinkan pemakai laporan keuangan dapat melihat laporan keuangan setiap saat dengan lebih cepat dan akurat.

Sistem informasi menyiratkan penggunaan teknologi komputer yang merupakan kombinasi dari perangkat lunak, perangkat keras dan manusia dalam pengolahan beberapa data untuk menghasilkan suatu informasi di mana data dikumpulkan, diproses menjadi informasi, dan didistribusikan kepada para pemakai yang dibutuhkan dalam pengambilan keputusan. Selain mendukung pengambilan keputusan, koordinasi dan pengawasan, sistem informasi dapat membantu manajer dalam menganalisa masalah, menvisualisasi masalahmasalah kompleks dan menciptakan produk-produk baru yang mampu mendukung kinerja karyawan dengan tujuan untuk mendukung dan memperbaiki operasional perusahaan.

Hal ini diperkuat oleh pernyataan yang disampaikan oleh Bodnar \& Hopwood (2010) bahwa Kualitas sistem informasi yang memenuhi keandalan akan dapat mengoptimalkan kinerja para pemakai. Pencapaian kinerja juga berkaitan dengan tugas, kebutuhan, dan kemampuan individu dalam organisasi, karena sistem informasi dalam organisasi akan menyesuaikan kebutuhan dan kemampuan individu Seiring dengan kemajuan teknologi, sistem informasi berkembang menjadi sistem informasi berbasis komputer sehingga dapat meningkatkan kinerja pengguna karena dapat dengan mudah melakukan akses untuk pengambilan keputusan. Proses pengambilan keputusan merupakan wujud pengalokasian sumberdaya. Informasi memiliki nilai ekonomis jika informasi tersebut dapat memfasilitasi keputusan pengalokasian sumber daya. Lebih lanjut Gowinda (2010:38) juga menyatakan bahwa "Kualitas sistem informasi merupakan sistem ciri karakteristik kualitas yang diinginkan dari sistem informasi itu sendiri, dan kualitas informasi yang diinginkan informasi karakteristik produk yang mendukung kinerja karyawan dalam menghasilkan informasi akuntansi".

"Produk" dari sistem informasi adalah informasi yang dihasilkan, dimana informasi tidak sama dengan data. Data adalah fakta, angka, bahkan simbol mentah. Secara bersamasama mereka merupakan masukan bagi suatu sistem informasi. Informasi terdiri dari data yang telah ditransformasi dan dibuat lebih bernilai melalui pemrosesan (Wilkinson, 2008). Kualitas informasi menunjukkan kualitas produk yang dihasilkan oleh aplikasi sistem informasinya dan informasinya akan mempunyai pengaruh pada pemakaiannya dan pada sistemnya. Kualitas informasi yang bermanfaat adalah relevan, akurat, tepat waktu, conciseness, jelas, dapat dikuantifikasi, dan konsisten. Semakin baik kualitas informasi, akan semakin tepat pula keputusan yang diambil. Kualitas dari suatu informasi (quality of information) tergantung dari tiga hal, yaitu informasi harus akurat (accurate), tepat pada waktunya (timely basis) dan relevan (relevance).

Menurut Jogiyanto (2010:15) Kualitas informasi dapat digunakan untuk mengukur kualitas keluaran dari sistem informasi. Kualitas informasi berupa dokumen operasional laporan yang terstruktur yang memiliki beberapa karakteristik yaitu relevan, tepat waktu, akurasi, kelengkapan, dan ringkas. Kualitas informasi merupakan model pengukuran yang berfokus pada keluaran yang diproduksi oleh sistem, serta nilai dari keluaran bagi pengguna sehingga mampu mengungkapkan kinerja pengguna sistem informasi, sedangkan DeLone \& McLean dalam teorinya seperti dikutip oleh Setyo (2015:3) menjelaskan bahwa kualitas sistem informasi akuntansi harus memenuhi keandalan sehingga dapat meningkatkan kinerjanya. Romney dan Steinbart (2014:12) menyatakan bahwa Kualitas informasi merujuk pada informasi yang dihasilkan oleh sistem informasi. Agar informasi yang disajikan dalam bentuk laporan dapat digunakan sebagai dasar pembuatan keputusan, maka dituntut untuk dapat menyajikan informasi yang relevan, akurat dan tepat waktu. 
Sebagai pengguna sistem informasi maka kepuasan pengguna akhir sistem informasi dapat dijadikan sebagai salah satu ukuran keberhasilan suatu sistem informasi (Oktaviana, 2013). Kepuasan pemakai terhadap suatu sistem informasi adalah bagaimana cara pemakai memandang sistem informasi secara nyata, tapi tidak pada kualitas sistem secara teknik. Dalam literatur penelitian, kepuasan pengguna sering kali digunakan sebagai ukuran pengganti dari efektivitas sistem informasi. Kinerja dalam penelitian ini berhubungan dengan pencapaian serangkaian tugas-tugas oleh individu. Kinerja lebih baik akan tercapai jika individu mendapatkan suatu penunjang untuk mempermudah pekerjaannya. Jadi apabila seseorang merasa puas terhadap sistem informasi yang digunakan, maka mereka akan cenderung untuk merasa nyaman dan aman selama bekerja dengan menggunakan sistem tersebut sehingga mereka akan merasa terbantu dalam menyelesaikan pekerjaan dalam hal ini kinerja karyawan akan meningkat.

Selain kualitas informasi, kualitas sistem informasi dan kepuasan pengguna, maka untuk mendukung kinerja karyawan tidak saja diperlukan kualitas informasi dan kualitas sistem akuntansi, tetapi juga tata kelola perusahaan yang baik dalam mengelola sumber daya yang dimiliki. Tata kelola perusahaan yang baik atau Good Corporate Governance (GCG) merupakan pedoman atau bisa digunakan sebagai formula untuk menciptakan pedoman bagi pengelola perusahaan dalam mengelola manajemen perusahaan yang baik dengan memperhatikan kepentingan stakeholders dengan tujuan untuk meningkatkan nilai tambah perusahaan bagi semua pihak yang berkepentingan sehingga secara langsung dapat meningkatkan kinerja manajemen.

Menurut Tunggal dan Widjaja (2013:1) “Good Corporate Governance merupakan sekumpulan hukum, peraturan, dan kaidah-kaidah yang wajib dipenuhi yang dapat mendorong kinerja sumber-sumber perusahaan bekerja secara efisien, menghasilkan nilai ekonomi jangka panjang yang berkesinambungan bagi para pemegang saham maupun masyarakat sekitar secara keseluruhan". Oleh karena itu, pengelolaan lembaga berdasarkan prinsip GCG pada dasarnya merupakan upaya untuk menjadikan GCG sebagai kaidah dan pedoman bagi pengelolaan lembaga dalam mengelola manajemen lembaga dalam mendukung kinerja karyawan yang secara tidak langsung dapat meningkatkan kinerja perbankan. Lebih lanjut Sedarmayanti (2012:57) menyatakan penerapan GCG dalam pengelolaan Bank sangat penting artinya karena secara langsung akan memberikan arahan yang jelas bagi bank untuk memungkinkan pengambilan keputusan secara bertanggung jawab dan memungkinkan pengelolaan Bank secara lebih amanah, sehingga dapat meningkatkan nilai Bank. Ada 5 prinsip yang dibutuhkan untuk membangun suatu budaya bisnis yang sehat, yaitu transparency (transparansi), accountability (akuntabilitas), responsibility (pertanggung jawaban), indepedency (kemandirian), dan fairness (kewajaran).

Secara empiris, penelitian ini didukung oleh beberapa penelitian terdahulu yang relevan dengan penelitin saat ini, dimana penelitian ini memasukkan variabel kualitas sistem informasi akuntansi, kualitas informasi akuntansi dan Good Corporate Governance untuk mengetahui apakah hal-hal teknis terkait perangkat lunak mempengaruhi kinerja karyawan. Pengujian terhadap kualitas sistem informasi dan kualitas informasi merupakan bagian untuk mengetahui apakah informasi yang dihasilkan sistem tersebut apakah memberikan dampak positif atau negatif bagi penggunanya. Kinerja pengguna sistem informasi akan dapat diketahui apabila informasi yang dihasilkan relevan, tepat waktu, dapat dipercaya, detail dan benar.

Kajian penelitian yang relevan dengan penelitian saat ini diantaranya dilakukan oleh Raminda (2014) yang berjudul "Pengaruh Kualitas Sistem, Kualitas Informasi Dan Kepuasan Pengguna Terhadap Kinerja Individu" di mana diperoleh hasil bahwa kualitas sistem, kualitas informasi dan kepuasan pengguna terbukti secara signifikan berpengaruh positif terhadap kinerja individu. Perbedaan yang mendasar antara penelitian terdahulu dengan penelitian 
yang sekarang adalah penelitian terdahulu menggunakan variabel kepuasan pengguan sebagai variabel ketiga sedangkan pada penelitian saat ini menggunakan Good Corporate Governance sebagai salah satu variabel yang juga diduga memiliki pengaruh terhadap kinerja karyawan.

Penelitian lain yang dilakukan oleh Dewi (2014) yang berjudul Pengaruh "Penerapan Prinsip-Prinsip Good corporate governance (GCG) Pada Kinerja Lembaga Perkreditan Desa Kabupaten Gianyar, Provinsi Bali" diperoleh hasil bahwa Good corporate governance berpengaruh positif terhadap kinerja LPD di Kabupaten Gianyar, Provinsi Bali. Penelitian yang sama juga dilakukan oleh Kholidah (2017) dengan judul "Pengaruh Penerapan PrinsipPrinsip Good Corporate Governance Terhadap Kinerja Pegawai" yang menunjukkan hasil bahwa Seluruh prinsip dari Good Corporate Governance berpengaruh positif terhadap kinerja pegawai, karena beberapa prinsip dari Good Corporate Governance dapat meningkatkan keterbukaan informasi mengenai perusahaan secara teratur dan tepat waktu serta benar.

Kedua penelitian tentang Good Corporate Governance ini menjadi dasar dalam menambahkan variabel GCG yang diduga memiliki pengaruh terhadap kinerja karyawan namun perbedaanya adalah pada penelitian terdahulu hanya meneliti tentang pengaruh GCG terhadap kinerja dengan pengembangan prinsip-prinsip GCG sebagai variabel sehingga menggunakan analisis regresi linier berganda namun penelitian saat ini lebih mengembangkan penelitian tidak sebatas menggunakna prinsip-prinsip GCG saja tetapi juga kualitas sistem informasi akuntansi dan kualitas informasi akuntansi yang juga berperan penting secara langsung dapat mempengaruhi kinerja karyawanya dalam aktivitasnya menyelesaikan pekerjaan secara efektif dan efisien.

Penelitian ini dilakukan di PT BPD Bali Cabang Singaraja dimana Bank ini sudah menerapkan sistem informasi akuntansi yang mempu menghasilkan kualitas informasi yang dibutuhkan oleh stakeholder dan merupakan bank pembangunan daerah yang beroperasi di Kabupaten Buleleng yang dimiliki oleh pemerintah Provinsi Bali. PT BPD Bali Cabang Singaraja merupakan perbankan yang bergerak dalam bidang jasa keuangan yang bersifat intermediasi yaitu menghimpun simpanan dari masyarakat berupa tabungan dan deposito kemudian menyalurkannya kembali dalam bentuk kredit sehingga untuk mendukung aktivitas tersebut maka dipandang perlu menerapkan sistem informasi akuntansi dalam menghasilkan kualitas informasi yang berguna bagi yang berkepentingan dan implementasi good Corporate governance yang baik sehingga memberikan informasi yang akurat demi meningkatkan kinerja manajemen dalam mengelola perusahaan dengan sebaik-baiknya.

Penggunaan sistem informasi di PT BPD Bali Cabang Singaraja dilakukan sejak tahun 2008 berbasis ERP menggunakan perangkat lunak SAP (system application product). SAP adalah suatu perangkat lunak yang mengintegrasikan berbagai aplikasi bisnis. PT BPD Bali Cabang Singaraja menggunakan paket SAP yang terdiri dari paket material management, financial management, human resources. Bagian keuangan dan akuntansi dan bagian administrasi menggunakan Financial management. Sedangkan bagian kepegawaian menggunakan paket human resources yang data outputnya terhubung dengan bagian keuangan dan akuntansi. SAP akan membantu pegawai dalam mengolah data dan menghasilkan data secara realtime. Hal ini dilakukan untuk memberikan pelayanan terbaik terhadap pelanggan, membantu kinerja pegawai agar efisien dan efektif, membantu manajer dalam mengontrol pegawai. Hasil observasi awal pada PT BPD Bali Cabang Singaraja diketahui bahwa terdapat beberapa karyawan yang kesulitan dalam menggunakan perangkat lunak sistem informasi akuntansinya karena belum semua karyawan memperoleh pendidikan dan pelatihan yang relevan dengan sistem yang digunakan. Disamping itu internet yang mendukung sistem informasi juga terkadang mengalami gangguan sehingga menghambat kinerja karyawan dalam melakukan pelayanan. Karyawan yang berumur lebih dari 50 tahun 
juga belum maksimal kinerjanya dalam menggunakan komputer sehingga sering pekerjaan harus dikejakan secara lembur.

Dalam teori yang disampaikan oleh DeLone \& McLean (dalam Setyo (2015) menjelaskan bahwa kualitas sistem informasi harus memenuhi keandalan sehingga dapat meningkatkan kinerja pengguna. Kualitas sistem informasi dapat diukur dengan ease of use (kemudahan penggunaan); response time (kecepatan akses) reliability (keandalan sistem) flexibility (fleksibilitas) dan security (keamanan).

Berdasarkan penelitian yang dilakukan oleh Amalia (2014) bahwa Variabel kualitas sistem informasi mempunyai pengaruh positif langsung terhadap kinerja perusahaan, dimana kualitas sistem informasi yang memenuhi keandalan akan dapat memuaskan pengguna dan mengoptimalkan kinerja sehingga perilaku pengguna akan mendukung penerapan teknologi informasi. organisasi akan menyesuaikan kebutuhan dan kemampuan individu.

Penelitian lain yang dilakukan oleh Setyo dan Rahmawati (2015) yang meneliti tentang "Pengaruh Kualitas Informasi Dan Kualitas Sistem Informasi Terhadap Kepuasan Serta Kinerja Pengguna Sistem Informasi" diperoleh hasil bahwa Kualitas Sistem Informasi berpengaruh positif terhadap Kinerja Pengguna Sistem Informasi. Hasil ini menunjukkan bahwa suatu perusahaan yang didukung dengan kualitas sistem informasi akuntan yang baik akan memberikan dampak terhadap kinerja karyawan dalam melaksanakan pekerjaanya sehingga tugas-tugas yang diberkan bisa selesai dengan cepat dan akurat, sehingga berdasarkan uraian di atas dapat dirumuskan hipotesis sebagai berikut.

$H_{1}:$ Kualitas Sistem berpengaruh positif terhadap kinerja karyawan

Harianur (2013) meyebutkan bahwa kinerja yang lebih baik tersebut tercapai karena dapat memenuhi kebutuhan individual dalam melaksanakan dan menyelesaikan tugas. Semakin tinggi kualitas informasi yang dihasilkan diprediksi akan berpengaruh terhadap semakin tingginya kinerja individu. Individu yang memiliki kinerja yang tinggi akan selalu berorientasi pada prestasi, memiliki percaya diri, berpengendalian diri, dan memiliki kompetensi. Pencapaian kinerja individu berkaitan dengan pencapain serangkaian tugas-tugas individu dengan dukungan teknlogi informasi yang ada. Semakin tingginya kualitas informasi yang dihasilkan oleh teknologi informasi, maka akan semakin baik kinerja individunya.

Menurut Jogiyanto (2010:15) Kualitas informasi dapat digunakan untuk mengukur kualitas keluaran dari sistem informasi. Kualitas informasi berupa dokumen operasional laporan yang terstruktur yang memiliki beberapa karakteristik yaitu relevan; tepat waktu; akurasi; kelengkapan; ringkas. Kualitas informasi merupakan model pengukuran yang berfokus pada keluaran yang diproduksi oleh sistem, serta nilai dari keluaran bagi pengguna yang dapat meningkatkan kinerja penggunanya.

Berdasarkan teori tentang pengaruh kualitas sistem informasi terhadap kinerja karyawan diperkuat dengan penelitian yang dilakukan oleh Raminda (2014) yang menemukan hasil bahwa kualitas informasi berpengaruh terhadap kinerja individu sehingga berdasarkan teori dan penelitian terdahulu maka maka dapat dirumuskan hipotesis penelitian sebagai berikut.

\section{$\mathrm{H}_{2}:$ Kualitas Informasi berpengaruh positif terhadap kinerja karyawan}

Kepuasan pengguna adalah respon para pengguna terhadap kinerja sistem informasi. Apakah para pengguna merasa suka dengan sistem informasi yang digunakan karena sesuai dengan harapan mereka dan mempermudah para pengguna dalam menyelesaikan tugasnya yang berhubungan dengan sistem informasi sehingga para pengguna dapat merasa puas. Seddon (dalam Istianingsih dan Utami, 2009) mendefinisikan kinerja individu ini sebagai pendapat pengguna atas sistem aplikasi khusus yang digunakan dalam meningkatkan kinerja mereka di dalam organisasi. Penilaiaan kinerja berhubungan dengan penyelesaian tugas-tugas 
tertentu, oleh pekerja, apakah berhasil atau gagal. Pencapaian ini juga perlu dikaitkan dengan perilaku dari pekerja selama proses penilaian. Kinerja dalam penelitian ini berhubungan dengan pencapaian serangkaian tugas-tugas oleh individu. Kinerja yang lebih baik akan tercapai jika individu mendapatkan suatu penunjang untuk mempermudah pekerjaannya.

Hubungan antara kepuasan pengguna akhir sistem informasi dengan kinerja individu ini telah diuji oleh Raminda (2014) menyatakan bahwa kepuasan pengguna sistem informasi terbukti secara signifikan berpengaruh positif terhadap kinerja individu sehingga berdasarkan penelitian terdahulu maka maka dapat dirumuskan hipotesis penelitian sebagai berikut.

$H_{3}$ : Kepuasan Pengguna Informasi akuntansi berpengaruh positif terhadap kinerja karyawan

Menurut Sedarmayanti (2012) menyatakan penerapan GCG dalam pengelolaan Bank sangat penting artinya karena secara langsung akan memberikan arahan yang jelas bagi bank untuk memungkinkan pengambilan keputusan secara bertanggung jawab dan memungkinkan pengelolaan Bank secara lebih amanah, sehingga dapat meningkatkan kinerja perbankan. Tunggal dan Widjaja (2013) juga menyatakan bahwa pengelolaan lembaga berdasarkan prinsip GCG pada dasarnya merupakan upaya untuk menjadikan GCG sebagai kaidah dan pedoman bagi pengelolaan lembaga dalam mengelola manajemen lembaga dalam mendukung kinerja karyawan yang secara tidak langsung dapat meningkatkan kinerja perbankan.

Good corporate governance merupakan faktor penting dalam menentukan nilai perusahaan dan berpengaruh terhadap kinerja perusahaan seperti pada bank. Hasil penelitian Kholidah (2017) menyatakan bahwa penerapan good corporate governance memberikan pengaruh yang positif dan signifikan terhadap kinerja bank. Pada hasil pnelitiannya mengemukakan bahwa penerapan Good Corporate Governance dalam kinerja pengguna sistem informasi merupakan kunci sukses bagi perusahaan untuk memperoleh keuntungan dalam jangka panjang dan dapat bersaing dengan baik dalam upaya meminimalkan risiko keputusan yang akan menguntungkan diri sendiri, sehingga meningkatkan kinerja pengguna sistem informasi yang pada akhirnya dapat memaksimalkan nilai perusahaan.

Penelitian lain yang dilakukan oleh Dewi (2014) menyatakan bahwa perusahaan yang sudah menerapkan good corporate governance dengan baik dan berkesinambungan akan mampu meningkatkan kinerja perusahaan. Berdasarkan hal tersebut maka dapat dirumuskan hipotesis sebagai berikut.

$H_{4}$ : Good corporate governance berpengaruh positif terhadap kinerja karyawan

\section{Metode}

Metode pengumpulan data dalam penelitian ini menggunakan survey dengan instrumen kuesioner. Hasil penyebaran kuesioner akan diolah terlebih dahulu dengan menggunakan uji validitas dan reliabilitas kemudian metode analisis data menggunakan uji asumsi klasik dan analisis regresi linier berganda. Hasil analisis tersebut akan memperoleh gambaran penelitian berupa angka-angka yang akan diinterpretasikan dalam bentuk sesuai dengan kenyataan di lapangan untuk memperoleh kesimpulan penelitian.

Populasi dalam penelitian ini adalah semua karyawan PT BPD Bali Cabang Singaraja sebanyak 101. Dalam menentukan jumlah sampel, tidak semua populasi di PT BPD Bali Cabang Singaraja dijadikan sebagai sampel sehingga agar memperoleh data yang tepat sesuai dengan karakteristik variabel yang diteliti maka penelitian menggunakan teknik penentuan jumlah sampel Purposive sampling. Pada penelitian ini, topik yang diangkat adalah mengenai sistem informasi akuntansi yang menyangkut kinerja pengguna sistem informasi dan good Corporate governance sehingga kriterianya penentuan sampel dengan teknik purposive 
sampling adalah Pegawai sudah bekerja lebih dari 5 (lima) tahun di Bank BPD, Pegawai yang terlibat langsung dalam menggunakan Sistem Informasi di Bank BPD Bali yaitu bagian administrasi, front liner (Customs Service \& teller), maintenance, bagian funding dan lending serta bagian lain yang terlibat langsung dengan sistem informasi, dan Pihak manajemen perbankan yang terlibat langsung dalam pengambilan keputusan teknis sehingga menciptakan good Corporate governance yang positif di mata nasabah dan pemerintah dalam hal ini adalah kepala bagian front liner, head officer dan bagian operasional. Berdasarkan kriteria pada teknik purposive sampling tersebut maka jumlah sampel yang digunakan adalah sebanyak 78 orang pegawai.

Metode analisis data yang digunakan adalah pertama, Uji Asumsi Klasik yang terdiri atas uji normalitas, uji multikolinieritas dan uji heteroskedastisitas. Selanjutnya hipotesis dianalisis dengan menggunakan Analisis Regresi linier Berganda, Analisis Determinasi, dan Analisis Uji T-Test dengan menggunakan SPSS Versi 21.0.

\section{Uji Kualitas Data}

Hasil pengujian validitas pada tabel di atas menunjukkan bahwa nilai Sig. (2-tailed) lebih kecil dari 0,05 dengan nilai Pearson Correlation (R-Hitung) lebih besar dari dari 0,227 (nilai r-tabel untuk $\mathrm{n}=78$ ) sebagai syarat valid sehingga dapat dikatakan instrumen pembentuk variabel valid untuk digunakan. Selanjutnya berdasakan hasil pengujian reliabilitas menunjukkan bahwa nilai Cronbach's Alpha lebih besar dari 0,70 sehingga dapat disimpulkan bahwa instrumen-instrumen pembentuk variabel adalah reliabel.

\section{Uji Asumsi Klasik}

Hasil pengujian normalitas data menunjukkan nilai kolmogorov-smirnov sebesar 0,084 dan tidak signifikan pada $0.05(0,084>0,05)$ menunjukkan bahwa residual terdistribusi secara normal

Hasil pengujian multikolinieritas menunjukkan nilai tolerance Kualitas Sistem Informasi $\left(\mathrm{X}_{1}\right)$ sebesar 0,031, Kualitas Informasi $\left(\mathrm{X}_{2}\right)$ sebesar 0,103, Kepuasan Pengguna Sistem $\left(\mathrm{X}_{3}\right)$ sebesar 0,022, Good Corporate Governance $\left(\mathrm{X}_{4}\right)$ sebesar 0,059 dimana nilai tolerance masing-masing variabel memiliki nilai > 0,10 kemudian nilai VIF Kualitas Sistem Informasi $\left(X_{1}\right)$ sebesar 2,734, Kualitas Informasi $\left(X_{2}\right)$ sebesar 9,701, Kepuasan Pengguna Sistem $\left(\mathrm{X}_{3}\right)$ sebesar 5,055, Good Corporate Governance $\left(\mathrm{X}_{4}\right)$ sebesar 6,943 yang menunjukkan nilai VIF > 10 sehingga dapat disimpulkan bahwa model regresi tidak terdapat multikolonieritas.

Pengujian Heteroskedastisitas dilakukan dalam sebuah model regresi dengan menggunakan uji Gletzer dengan tujuan bahwa apakah suatu regresi tersebut terjadi ketidaksamaan varians dari residual dari satu pengamatan ke pengamatan lain dimana hasilnya menunjukkan bahwa bahwa ketiga variabel memiliki nilai Sig. > 0,05, variabel Kualitas Sistem Informasi sebesar 0,327, Kualitas Informasi sebesar 0,418, Kepuasan Pengguna Sistem sebesar 0,130 dan good Corporate governance sebesar 0,915 yang memilliki nilai lebih besar dari 0,50 sehingga dapat disimpulkan bahwa tidak ada gejala heteroskedastisitas.

\section{Hasil dan Pembahasan}

Berdasarkan hasil perhitungan analisis regresi dengan menggunakan program SPSS versi 21.0 For Windows terkait dengan variabel yang diteliti yaitu pengaruh kualitas sistem, kualitas informasi akuntansi, kepuasan pengguna dan good corporate governance terhadap kinerja karyawan dapat disajikan dalam tabel berikut.

Tabel 1. Hasil Analisis Regresi

\begin{tabular}{ccccccc}
\hline Model & $\begin{array}{c}\text { Unstandardized } \\
\text { Coefficients }\end{array}$ & $\begin{array}{c}\text { Standardized } \\
\text { Coefficients }\end{array}$ & T & Sig. & Coefficients \\
\hline
\end{tabular}




\begin{tabular}{ccllll}
\hline \multicolumn{7}{c}{ B } & Std. Error & Beta & & \\
\hline (Constant) & 2,077 & 0,628 & & 3,305 & 0,001 \\
\hline $\mathrm{X}_{1}$ & 0,891 & 0,115 & 0,417 & 7,774 & 0,000 \\
\hline $\mathrm{X}_{2}$ & 0,232 & 0,071 & 0,096 & 3,281 & 0,001 \\
\hline $\mathrm{X}_{3}$ & 0,477 & 0,081 & 0,372 & 5,907 & 0,000 \\
\hline R Square & & & & &, 992 \\
\hline
\end{tabular}

Sumber : data primer (data diolah)

Berdasarkan hasil pengolahan data pada penelitian ini ditentukan persamaan regresi linier berganda sebagai berikut.

$\mathrm{Y}=2,077+0,891\left(\mathrm{X}_{1}\right)+0,232\left(\mathrm{X}_{2}\right)+0,477\left(\mathrm{X}_{3}\right)+0,125\left(\mathrm{X}_{4}\right)$

$\mathrm{Y}=2,077+0,891$ (Kualitas Sistem Informasi) $+0,232$ (Kualitas Informasi) $+0,477$ (Kepuasan Pengguna Sistem) + 0,125 (Good Corporate Governance)

Pertama, Kualitas Sistem Informasi berpengaruh terhadap Kinerja karyawan PT BPD Bali Cabang Singaraja sebesar 0,891 satuan dengan hasil uji T-Test didapatkan bahwa thitung > t-tabel $(7,774>1.66437)$ sehingga hipotesis diterima yakni "Kualitas Sistem Informasi berpengaruh positif dan signifikan terhadap Kinerja karyawan PT BPD Bali Cabang Singaraja".

Kedua, Kualitas Informasi berpengaruh terhadap Kinerja karyawan PT BPD Bali Cabang Singaraja sebesar 0,232 satuan dengan hasil pengujian hipotesis menggunakan uji TTest menunjukkan bahwa t-hitung $>$ t-tabel $(3,281>1.66437)$ sehingga hipotesis diterima yakni "Kualitas Informasi berpengaruh positif dan signifikan terhadap Kinerja karyawan PT BPD Bali Cabang Singaraja".

Ketiga, Kepuasan Pengguna Sistem berpengaruh terhadap Kinerja karyawan PT BPD Bali Cabang Singaraja sebesar 0,477 satuan dengan hasil pengujian hipotesis menggunakan uji T-Test menunjukkan bahwa t-hitung > t-tabel $(5,907>1.66437)$ sehingga hipotesis diterima yakni "Kepuasan Pengguna Sistem berpengaruh positif dan signifikan terhadap Kinerja karyawan PT BPD Bali Cabang Singaraja".

Keempat, Good Corporate Governance berpengaruh terhadap Kinerja karyawan PT BPD Bali Cabang Singaraja sebesar 0,125 satuan dengan hasil uji T-Test didapatkan bahwa thitung > t-tabel $(43,212>1.66437)$ sehingga hipotesis diterima yakni "Good Corporate Governance berpengaruh positif dan signifikan terhadap Kinerja karyawan PT BPD Bali Cabang Singaraja".

Kelima, Besarnya nilai koefisien determinasi dapat dilihat dari nilai $R$ square yaitu sebesar 99,6\%. Ini berarti bahwa Kualitas Sistem Informasi $\left(X_{1}\right)$, Kualitas Informasi $\left(X_{2}\right)$, Kepuasan Pengguna Sistem $\left(\mathrm{X}_{3}\right)$ Good Corporate Governance $\left(\mathrm{X}_{4}\right)$ secara bersama-sama mempengaruhi Kinerja karyawan (Y) sebesar 99,6\% dan sisanya sebesar 100\% - 99,6\%= $0,4 \%$ dipengaruhi oleh faktor lain yang tidak diteliti dalam penelitian ini.

\section{Pengaruh Kualitas Sistem Informasi $\left(X_{1}\right)$ Terhadap Kinerja karyawan $(Y)$}

Berdasarkan hasil penelitian menunjukkan bahwa Kualitas Sistem Informasi berpengaruh terhadap Kinerja karyawan PT BPD Bali Cabang Singaraja sebesar 0,891 satuan dengan hasil uji T-Test didapatkan bahwa t-hitung > t-tabel $(7,774>1.66437)$ sehingga hipotesis diterima yakni "Kualitas Sistem Informasi berpengaruh positif dan signifikan terhadap Kinerja karyawan PT BPD Bali Cabang Singaraja".

Hasil ini menunjukkan bahwa dalam meningkatkan kinerja karyawan pada PT BPD Bali Cabang Singaraja maka harus didukung oleh kualitas sistem yang baik sehingga memudahkan karyawan dalam bekerja tanpa ada gangguan yang berarti berkaitan dengan sistem informasi yang ada pada perusahaan. kualitas sistem yang baik dapat menghasilkan informasi yang akurat dan efisien. Demikian halnya pada PT BPD Bali Cabang Singaraja 
menunjukkan bahwa selama ini karyawan puas dengan kualitas sistem yang ada pada perusahaan sehingga mampu meningkatkan kinerja karyawan dalam mendongkrak peningkatan laba dana penyelesaian pekerjaan yang lebih efektif.

Hasil ini sejalan dengan penelitian yang dilakukan oleh penelitian yang dilakukan oleh Amalia (2014) serta Setyo dan Rahmawati (2015) bahwa Variabel kualitas sistem informasi mempunyai pengaruh positif dan signifikan terhadap kinerja karyawan.

\section{Pengaruh Kualitas Informasi $\left(X_{2}\right)$ Terhadap Kinerja karyawan $(Y)$}

Berdasarkan hasil penelitian menunjukkan bahwa Kualitas Informasi berpengaruh terhadap Kinerja karyawan PT BPD Bali Cabang Singaraja sebesar 0,232 satuan dengan hasil pengujian hipotesis menggunakan uji T-Test menunjukkan bahwa t-hitung $>$ t-tabel $(3,281>$ 1.66437) sehingga hipotesis diterima yakni "Kualitas Informasi berpengaruh positif dan signifikan terhadap Kinerja karyawan PT BPD Bali Cabang Singaraja".

Hasil ini menunjukkan bahwa dengan kualitas informasi pada PT BPD Bali Cabang Singaraja pada saat ini masih dalam keadaan yang baik sehingga mampu meningkatkan kinerja karyawan. kualitas informasi dalam hal ini adalah kualitas output yang berupa informasi yang dihasilkan oleh sistem informasi yang digunakan. Semakin baik kualitas informasi, akan semakin tepat pula keputusan yang diambil oleh perusahaan. Apabila informasi yang dihasilkan tidak berkualitas, maka akan berpengaruh negatif pada kepuasan pemakai sehingga kinerja individu akan terganggu dan berdampak pada kinerja karyawan.

Hasil ini sejalan dengan hasil penelitian yang dilakukan oleh Harianur (2013) dan Raminda (2014) bahwa kualitas informasi mempunyai pengaruh positif dan signifikan terhadap kinerja karyawan.

\section{Pengaruh Kepuasan Pengguna Sistem $\left(X_{3}\right)$ Terhadap Kinerja karyawan $(Y)$}

Berdasarkan hasil penelitian menunjukkan bahwa Kepuasan Pengguna Sistem berpengaruh terhadap Kinerja karyawan PT BPD Bali Cabang Singaraja sebesar 0,477 satuan dengan hasil pengujian hipotesis menggunakan uji T-Test menunjukkan bahwa t-hitung $>\mathrm{t}$ tabel $(5,907>1.66437)$ sehingga hipotesis diterima yakni "Kepuasan Pengguna Sistem berpengaruh positif dan signifikan terhadap Kinerja karyawan PT BPD Bali Cabang Singaraja”.

Hasil ini menunjukkan bahwa kepuasan pengguna merujuk pada sikap umum seorang individu terhadap pekerjaannya. Seseorang dengan tingkat kepuasan kerja tinggi menunjukkan sikap positif terhadap pekerjaan yang dilakukan sehingga mampu meningkatkan kinerja individu dalam menyelesaikan pekerjaannya. Dampak dari kepuasan penggunaan sistem informasi yang berupa meningkatnya kinerja individu. Jika seseorang merasa puas terhadap sistem informasi yang digunakan, maka mereka akan cenderung untuk merasa nyaman dan aman selama bekerja dengan menggunkan sistem tersebut sehingga mereka akan merasa terbantu dalam menyelesaikan pekerjaan. Diprediksi bahwa semakin tinggi tingkat kepuasan pengguna akan suatu sistem informasi, maka akan semakin tinggi juga kinerja mereka.

Hasil ini sejalan dengan penelitian terdahulu yang dilakukan oleh Setyo dan Rahmawati (2015) serta penelitian yang dilakukan oleh Istianingsih dan Utami (2009) bahwa kepuasan pengguna system informasi berpengaruh terhadap kinerja karyawan.

\section{Pengaruh Good Corporate Governance $\left(X_{4}\right)$ terhadap Kinerja Karyawan $(Y)$}

Berdasarkan hasil penelitian menunjukkan bahwa Good Corporate Governance berpengaruh terhadap Kinerja karyawan PT BPD Bali Cabang Singaraja sebesar 0,125 satuan dengan hasil uji T-Test didapatkan bahwa t-hitung > t-tabel $(43,212>1.66437)$ sehingga 
hipotesis diterima yakni "Good Corporate Governance berpengaruh positif dan signifikan terhadap Kinerja karyawan PT BPD Bali Cabang Singaraja”.

Hasil ini menunjukkan bahwa Penerapan GCG dalam pengelolaan perbankan sangat penting artinya karena secara langsung akan memberikan arahan yang jelas bagi perbankan untuk memungkinkan pengambilan keputusan secara bertanggung jawab dan memungkinkan pengelolaan perbankan secara lebih amanah, sehingga dapat meningkatkan nilai perbankan. Ada 5 prinsip yang dibutuhkan untuk membangun suatu budaya bisnis yang sehat, yaitu transparency (transparansi), accountability (akuntabilitas), responsibility (pertanggung jawaban), indepedency (kemandirian), dan fairness (kewajaran) yang berpengaruh langsung terhadap kinerja karyawan.

Hasil ini sejalan dengan penelitian yang dilakukan oleh Kholidah (2017) dan Dewi (2014) bahwa penerapan good corporate governance memberikan pengaruh yang positif dan signifikan terhadap kinerja karyawan.

\section{Implikasi}

Berdasarkan hasil penelitian yang sudah di jelaskan sebelumnya amak dapat dikemukakan implikasi secara teoritis dan praktis. Secara teoritis penelitian ini dapat dijeadikan sebagai bahan informasi atau pengetahuan tambahan mengenai pengaruh kualitas sistem informasi, Kualitas Informasi akuntansi, kepuasan pengguna dan Good Corporate Governance terhadap kinerja karyawan serta dapat dijadikan acuan bagi peneliti lain yang ada hubungannya dengan penulisan karya ilmiah.

Secara praktis Bagi PT BPD Bali Cabang Singaraja dalam rangka meningkatkan kinerja karyawan maka perlu diperhatikan faktor-faktor yang mempengaruhinya, khusunya pada Sistem Informasi Akuntansi perlu diperhatikan kualitas sistem informasi dan Kualitas Informasi akuntansi kemudian dengan penerapan SIA tersebut perlu juga diperhatikan kepuasan pengguna dalam menggunakan system tersebut dan Good Corporate Governance sehingga dapat meningkatkan kinerja. Oleh karena itu, PT BPD Bali Cabang Singaraja memperhatikan Kualitas sistem informasi, Kualitas Informasi akuntansi, kepuasan pengguna dan Good Corporate Governance dalam kegiatan operasional perbankan karena memiliki dampak yang positif dalam peningkatan kinerja karyawan sehingga apabila kinerja karyawan meningkat maka pelayanan kepada nasabah juga akan maksimal sesuai dengan harapan perusahaan, kemudian Bagi pemerintah memberikan dampak bahwa dalam meningkatkan kinerja kayawan maka perlu diperhatikan kualitas sistem informasi, Kualitas Informasi akuntansi, kepuasan pengguna dan Good Corporate Governance, sehingga pemerintah bisa menerapkan kebijakan strategi melalui rencana strategis baik jangka pendek maupun jangka panjang dalam meningkatkan kinerja baik melalui Pendidikan pelatihan maupun maupun pemanfaatan teknologi informasi.

\section{Simpulan dan Saran}

Pertama, Variabel Kualitas Sistem Informasi berpengaruh positif dan signifikan terhadap Kinerja karyawan, yang ditunjukkan dengan koefisien regresi yang positif sebesar 0,891 dan nilai probabilitas uji T sebesar 0,000 yang lebih kecil dari $\alpha=5 \%$. Artinya Apabila Kualitas Sistem Informasi dipatuhi maka Kinerja karyawan akan semakin meningkat.

Kedua, Variabel Kualitas Informasi berpengaruh positif dan signifikan terhadap Kinerja karyawan, yang ditunjukkan dengan koefisien regresi yang positif sebesar 0,232 dan nilai probabilitas uji $\mathrm{T}$ sebesar 0,038 yang lebih kecil dari $\alpha=5 \%$. Artinya Apabila Kualitas Informasi ditingkatkan maka akan mampu meningkatkan Kinerja karyawan.

Ketiga, Variabel Kepuasan Pengguna Sistem berpengaruh positif dan signifikan terhadap Kinerja karyawan, yang ditunjukkan dengan koefisien regresi yang positif sebesar 0,477 dan nilai probabilitas uji T sebesar 0,000 yang lebih kecil dari $\alpha=5 \%$. Artinya Apabila 
Kepuasan Pengguna Sistem semakin meningkat maka akan Kinerja karyawan juga akan semakin tinggi.

Adapun saran pada penelitian ini yaitu Pertama, Hendaknya PT BPD Bali Cabang Singaraja meningkatkan kualitas informasi dan kualitas sistem yang ada di perusahaan dengan memperbaharui sistem informasi yang ada dengan system yang terbaru, menjaga kualitas jaringan dan internet yang digunakan serta mengadakan pelatihan dalam penggunaan teknologi informasi sehingga penyelesaian pekerjaan lebih efektif dan efisien.

Kedua, Hendaknya PT BPD Bali Cabang Singaraja meningkatkan kepuasan pengguna sistem informasi. Meningkatkan kepuasan pengguna ini tentu saja harus didukung dengan Teknologi sistem informasi yang mudah digunakan serta mudah dimengerti dan dipahami oleh pengguna. oleh karena itu PT BPD Bali Cabang Singaraja harus mengevaluasi penggunakan sistem informasi yang digunakan dimana hal ini perlu dilakukan untuk meningkatkan kinerja karyawan.

Ketiga, Hendaknya PT BPD Bali Cabang Singaraja harus tetap menjaga nama baik perusahaan (Good Corporate Governance) dengan menekankan prinsip transparency (transparansi), accountability (akuntabilitas), responsibility (pertanggung jawaban), indepedency (kemandirian), dan fairness (kewajaran) serta mengembangkan prinsip-prinsip Good Corporate Governance melalui pihak manajemen dan karyawan sehingga semua lapisan yang terlibat pada PT BPD Bali Cabang Singaraja memahami prinsip Good Corporate Governance sehingga akan senantiasa menjaga nama baik perusahaan dan secara langsung akan meningkatkan kinerja mereka.

Keempat, Bagi mahasiswa lain yang berminat meneliti masalah pengaruh Kualitas Sistem Informasi, Kualitas Informasi, Kepuasan Pengguna Sistem dan Good Corporate Governance terhadap Kinerja karyawan agar mengembangkan penelitian ini lebih lanjut dan mempertimbangkan variabel lain yang belum diuji dalam penelitian ini dimana diketahui bahwa pengaruh ketiga variabel terhadap kinerja karyawan adalah sebesar $99,6 \%\left(\mathrm{R}^{2}\right)$ dan terdapat sebesar $0,4 \%$ dipengaruhi oleh faktor lain maka perlu dilakukan penelitian lebih lanjut tentang faktor-faktor yang diduga berpengaruh terhadap kinerja karyawan sepertti teknologi informasi, produk system informasi, dukungan manajemen puncak, kemampuan Teknik personal, program pendidikan dan pelatihan teknik pemakai sistem, kepercayaan dan kepuasan pengguna sistem informasi akuntansi. Hal ini sesuai dengan kajian penelitian sebelumnya serta berdasarkan teori yang menunjukkan bahwa banyak faktor yang mempengaruhi kinerja karyawan serta mengembangkan metode analisis data dengan menggunakan analisis path.

Kelima, Mengingat Kualitas Sistem Informasi, Kualitas Informasi, Kepuasan Pengguna Sistem dan Good Corporate Governance berpengaruh positif dan signifikan terhadap Kinerja karyawan maka dalam meningkatkan kinerja tidak saja perlu dipertimbangkan oleh pihak perbankan tetapi juga oleh instansi pemerintah sehingga instansi pemerintah juga bisa memperhatikan variabel-variabel yang bisa mempengaruhi kinerja karyawan sesuai dengan variabel yang digunakan dalam penelitian ini. Hal ini bertujuan untuk meningkatkan pelayanan kepada masyarakat serta diharapkan dapat menghilangkan kesan yang negatif dalam hal kinerja kepada aparatur pemerintah.

\section{Daftar Pustaka}

Amalia, Rizki Fitri. 2014. Pengaruh Kualitas Sistem Informasi Dan Kualitas Informasi Dalam Penggunaan Sistem Informasi Akuntansi Terhadap Kinerja Perusahaan (Studi Empiris Pada Perusahaan Manufaktur Yang Terdaftar Di Bursa Efek Indonesia). Jurnal Ilmiah STIE MDP. Forum Bisnis Dan Kewirausahaan. Vol. 3 No. 2. Hal. 87 - 102.

Bodnar, George H, and S.Hopwood William. 2010. Sistem Informasi Akuntansi. Edisi 
Kedelapan. Jakarta: Jilid 1. PT.Indeks.

Darma, Agus. 2009. Manajemen Prestasi Kerja. Jakarta: CV. Rajawali.

Dewi, Kadek Krismaya. 2014. Pengaruh Penerapan Prinsip-Prinsip GCG Pada Kinerja Keuangan Lembaga Perkreditan Desa Kabupaten Gianyar, Provinsi Bali. E-Jurnal Akuntansi Universitas Udayana ISSN: 2302-8556 Vol. 8, No.1 Hal: 70-82.

George dan Jones. 2009. Understanding and Managing Organizational Behaviour 4 Pearson. Prentice Hall.

Gowinda, Gita. 2010. Analisis Perilaku Penerimaan Wajib Pajak terhadap Penggunaan EFilling (Kajian Empiris Wilayah Kota Semarang). Skripsi. Semarang : Fakultas Ekonomi Universitas Dipenogoro.

Hall, James A. 2007. Sistem Informasi Akuntansi. Edisi keempat. Salemba Empat. Jakarta.

Harianur, Indra R. 2013. Pengaruh Kualitas Informasi Terhadap Kinerja Individu: Kepuasan Pengguna Sebagai Variabel Intervening (Survey Terhadap Karyawan Yang Menggunakan Sistem RPPS Di UMS). Skripsi tidak diterbitkan. Fakultas Ekonomi Dan Bisnis Jurusan Akuntansi. Universitas Muhammadiyah Surakarta.

Istianingsih dan W. Utami. 2009. Pengaruh Kepuasan Pengguna Sistem Informasi Terhadap Kinerja Individu (Studi Empiris pada Pengguna Paket Program Aplikasi Sistem Informasi Akuntansi di Indonesia). Skripsi. Universitas Mercubuana. Palembang.

Jogiyanto, HM. 2010. Sistem Informasi Strategik. Yogyakarta : Andi.

Kholidah, Nur. 2017. Pengaruh Penerapan Prinsip-Prinsip Good Corporate Governance Terhadap Kinerja Pegawai. Jurnal Ilmu dan Riset Akuntansi. Volume 6, Nomor 3, Maret 2017. ISSN : 2460-0585

Oktaviana, Dian Lani. 2013. Analisis Faktor - Faktor Yang Mempengaruhi Kepuasan Pengguna Sistem Informasi Terhadap Kinerja Individu (Dua Faktor Sebagai Variabel Anteseden). Skripsi. Fakultas Ekonomi Dan Bisnis Jurusan Akuntansi. Universitas Muhammadiyah Surakarta

Raminda, All Nitri Ayu. 2014. Pengaruh Kualitas Sistem, Kualitas Informasi Dan Kepuasan Pengguna Terhadap Kinerja Individu. Jurnal Ilmu \& Riset Akuntansi Vol. 3 No. 9

Sedarmayanti. 2012. Good Corporate Governance. Cetakan Ketiga. Bandung: PT. Refika Aditama.

Setyo, Dekeng B dan Dessy Ari Rahmawati. 2015. Pengaruh Kualitas Informasi Dan Kualitas Sistem Informasi Terhadap Kepuasan Serta Kinerja Pengguna Sistem Informasi. EfEktif Jurnal Bisnis dan Ekonomi. Vol. 6, No 1, Juni 2015, 47 - 59

Tunggal, Imam Sjahputra dan Amin Widjaja Tunggal. 2013. Good Corporate Governance. Jakarta: Sinar Grafika.

Wilkinson. 2008. Sistem Akunting dan Informasi. Edisi Ketiga. Jilid Satu. Jakarta Barat: Binarupa Aksara. 